\title{
Institutional Traps of Human Capital Consumption: Public Goods Production Problems
}

\author{
Alekseeva L.V. \\ Kazan Federal University, Institute of Management, Economics and Finance, Kazan, 420008, Russia
}

Nikonova T.V.

Kazan Federal University, Institute of Management, Economics and Finance, Kazan, 420008, Russia

Yusupova L.M.

Kazan Federal University, Institute of Management, Economics and Finance, Kazan, 420008, Russia

Email address:viktta@mail.ru

\section{Doi:10.5901/mjss.2014.v5n24p131}

\begin{abstract}
Taking into consideration the importance of human capital resource, many countries had initiated national research aimed at assessment of national human capital and its contribution to national wealth and economic growth. Top human capital index and global competitiveness index in a cross-section of regions were recorded in North America, Europe and Central Asia. Human capital consumption appears as one of its reproduction aspects. But effect generated in the process of human capital consumption differs in different countries. It is explained by diversity of institutional environment, the elements of which may form self-sustained ineffective stable relations, i.e institutional traps that hamper the effective consumption of human capital. In this article authors attempted to reflect on matter of institutional traps, stipulating restrictions in human capital consumption which derive from public goods production and granting of social guarantees. Origins of appearance and rooting mechanisms of two types of institutional traps have been studied in the context of a number of countries: surplus production of public goods and underproduction of public goods and social guarantees. Research outcomes make it possible to review the approaches to settlement of modern problems in development and consumption of human capital as a resource in developed and underdeveloped countries.
\end{abstract}

Keywords: human capital, public goods, social guarantees, paternalism, institutional trap, ageing of population, dependency, employment.

\section{Introduction}

Human capital in present global economics is interpreted during the past decades as key resource for intensive development and prospect for competitive advantage. Understanding of importance of human capital as economic growth resource and driving force came with publications of Becker G.[1], Schultz T.[2], Mincer J.[3] who were awarded later the Nobel prize, in 1960-s.

In follow-up works in 1990-s, human capital resource was recognized the basic notion of sustainable development concept. In the late 20th century expert group headed by J. Dickson was founded under the aegis of the World Bank , aimed at advancement of updated national wealth concept, methodology development and structural components computation [4].

Taking into consideration the importance of human capital resource, many countries had initiated national research aimed at assessment of national human capital and its contribution to national wealth and economic growth. So, in accordance with report of the World Economic Forum on human capital in 2013, top human capital index and global competitiveness index in a cross-section of regions were recorded in North America, Europe and Central Asia, and lowest index - in the Middle East and in Africa.[5][6] Their direct relation was proved statistically.

Recent research held by Abbas $\mathrm{K}$. in relation to experience of rapid accumulation of physical capital in underdeveloped countries, confirmed relevancy of emphasis to development of human capital, since it's obvious that effective use of physical capital in its turn depends on the state of consumed human capital.[7]

Human capital consumption is seen as part of its reproduction, precisely, the process of realization in the course of business of standard and specialized, including idiosyncratic resources in the form of knowledge, skills, proficiency and 
professional competence.

Thereat standard human capital resources are formed in the process of pre-school and secondary-level education, enjoyment of traditional medical services. Highly specialized resources are formed in the process of secondary and higher professional education upon condition of low level of educational services individualization.

It is worth to note, that effect generated in the process of human capital consumption differs in different countries. It may explained by differences in institutional environment of countries where human capital is consumed.

In its turn, constitutional environment is represented by fundamental political, social and legal rules, which form the basis for the process of extracting benefits and useful effects from human capital at all levels of economy.

Unfortunately, in the present state of economy interaction of the said institutions may result in self-sustained ineffective relations, i.e. institutional traps.

In this article we make an attempt to reflect on matter of institutional traps, stipulating restrictions in human capital consumption which derive from public goods production.

\section{Institutional Trap Logic of Surplus Production of Public Goods}

In recent researches quality and volume of public goods production, especially of individual ones (such as education and healthcare), first of all are related with the process of human capital accumulation. For example, the role of education in human capital growth is studied in works by Fuentedela A., Jimeno J.[8], Joshua C.[9], Lee J., Barro R.[10], the role of medicine and healthcare - in works by Janet C.[11], Johnson R., Schoeni R.[12].

At the same time, there exists the reverse of public goods production, effecting uniformity and efficiency (in time and space) of human capital consumption.

In modern economy quality standards and quantity of public goods are set by the state as main producer of the said goods. Private sector in most cases is not interested in production of those goods. It may be explained by their high costs with concurrent extension of benefits to all participants in the economic process, including those, who did not incur costs. Volume and quality of public goods considerably differed at different times and for different countries, demonstrating some or other state priorities..

The sphere of public goods and social guarantees takes a certain scope of social functions, aimed at, first of all, direct formation of human capital (goods of education, healthcare, culture, physical culture spheres), second, implied participation in human capital accumulation ( including defence, public security, municipal improvement and environmental protection, mass media).

Public goods supply contributes for public habit-forming to them, increasing welfare and becoming a permanent characteristic of a shaped living standard. It has an impact on direct effects of human capital consumption in the form of growth of real income of the population. In reality, Samuelson Pareto principle of public goods optimal production not always is realized in practice. It means that public goods trap takes place both in situation of production surplus, and in case of underproduction of public goods.

There may be many reasons for imbalance. As fairly noted by American professor J.E.Stiglitz, under circumstances when the state undertakes a great scope of paternal responsibility, one citizen group may impose its will and preferences via bodies of government on other social groups, as well as their conviction of how to behave and what to consume [13]. Besides, in a competition-constrained environment, state monopolies granting public goods may make non-optimal use of resources.

Surplus production of public goods in terms of human capital accumulation has a number of positive effects, in particular, growth and enhancement of national human capital as the result of improvement of education level, health promotion, scientific and cultural development.

In the context of human capital consumption, surplus production of public goods provokes dependency in the society, thus decreasing human capital efficiency.

History of the part century shows us negative consequences of total governmentalization of social services. Quite evident are such factors of breakdown of such policy as tendency towards monopolization of state power by bureaucracy, chasing political rent, resource-cost characteristics of economic mechanism of public decisions in the absence of competitions, social dependency development.

Contemporary history of developed countries also has examples of institutional traps of surplus production of public goods and social guarantees. Serious unrest in a number of European cities that take place in recent years ( the most vivid example is Paris) is explained with unbalanced migration policy, encouraging migration from underdeveloped countries.

For example, after Algeria has gained independence in 1962, population of France has increased almost to 42 
thousand immigrants from the former colony. Introduction of migrants employment programme in 1950-60-s resulted in rapid increase of migrant inflow from African Muslim countries. The same effect was observed in other European countries that encouraged labour migration, i.e. FRG, Great Britain [14].

The launched further on migrant family reunification programme and multiculturalism policy [15], when the state guarantees to its cultural minorities the possibility of full participation in cultural life and preservation of their identity, and undertakes obligations (including financial ones) concerning security of such guarantees, had resulted in growth of social dependency. In particular, the chosen national policy had provided for the use of wide, customary for the developed world set of social policy instruments for migrants. This inevitably resulted in inappropriate perception of incentives by the migrants. So, introduction (or increase) of maternity allowance was aimed to motivate women who are involved in public production, to leave work temporarily. But many of migrant women, in line with customary living and values, prefer not to work, and allowance (coupled with high-quality public goods and high demands to life standards) fixes stereotypes of dependant behaviour, forms ineffective human capital. As a result, in the early 21 century, nearly 65 percent of immigration to France was due to family reunification [16].

In further increase of public goods production and progress of social guarantees, human capital hampers national economic development. When French government undertook an expensive measure of granting social dwelling to migrants in Paris suburbs, the dependant mode of behaviour of the second migrant generation had deep-rooted. Financial crisis that came next in 2008-2009, which made in impossible to maintain further social policy at the same level, had resulted in mass protests. It is worth to note that at the present moment, the quantity of migrants from former French colonies equals nearly to 6 million. According to the data of International Labour Organization, one third of the world's migrants (56 million) live in Europe, 27,5 million of them conduct activities there. In some countries, for example, in Luxembourg and Switzerland the share of foreigners in total workforce reaches $25 \%$.

The trap of surplus production of public goods may cover not only human capital with underestimated stereotypes concerning quality and quantity of social guarantees and public goods. Such dependant behaviour may be provoked among the person who attained pension age, able to work, but preferring inactivity due to weak return-to-work and qualification incentives, supported by extended public goods and indistinction between living standards of non-working pensioners and workers of productive age.

The problem of non-working human capital of pensioners is especially pressing in ageing baby boomer countries. For example, in Iceland average pension reaches $96,5 \%$ of employed net income, in general in EC countries this index may vary within $65 \%$, while average American may build upon pension that equals to $39 \%$ of their pre-pension income.

In Russia this index equals to $33,5 \%$, and in China traditionally welfare for the aged lies on children rather than the pension system.

The staged scheme of consolidation of traps of surplus production of public goods and social guarantees is shown in Figure 1.

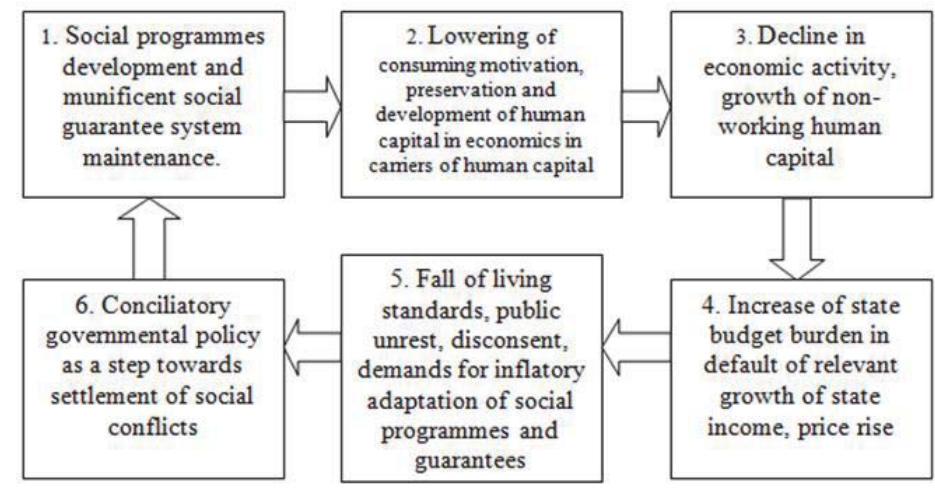

Fig. 1. Traps of surplus production of public goods and social guarantees.

Surplus production of public goods and munificent social guarantees increase budget expenditure and do not stimulate economic activity of the country.

Over a period f years such policy would dependency habit of population. Any attempt by state authorities to escape such policy would be followed by popular discontent and even hostility, which may be observed now in some European countries. 


\section{Traps of Underproduction of Public Goods}

Let us turn to institutional trap of underproduction of public goods and social guarantees. It is quite obvious, that the lower is quality and quantity of public goods and social guarantees, the more the population has to spend on purchase of paid required goods (especially in the sphere of education, healthcare, security and so on). On the one hand, underproduction of public goods increases human capital efficiency, setting for maximal efficiency, use of knowledge, skills, experience, physical and mental abilities. Availability of services for a pay would set up people for labour activity towards acquisition of income.

On the other hand, underproduction directly results in underconsumption.

Theory of economy and modern age allow to specify following reasons that drag human capital into a trap of human capital underproduction:

1. Rushed economic and social progress that outrun the progress of public goods and social guarantees. In terms of industrial growth, the population pays more attention to matters of education, healthcare and social security, has higher demand for fairness. This is the character of public goods underproduction trap of modern China. For the past 35 years, with spring of the policy of reforms and economic openness, China had overcame the problem of lack of material resources, increased personal income, but underproduction of public goods of educational sphere, medicine and social security had formed new barriers in development of society. Labour unrest became more frequent and more intensive. For example, according to the data from WHO Department of Health Statistics and Informatics, in average medical service payments amount to nearly $12 \%$ of household budget in China after expenses for meal. State healthcare expenditure in China amounts to $5 \%$ of GDP of Chine, as reported by WHO, which takes 111 position in global rate (364 dollars per capita in PPP), the similar index for the USA equals to 17\% of GDP, and for European countries 8-12\% of GDP[17]. Weak healthcare financing in China in recent years exposes families to risk to sink into poverty, which happened to be in the late 1990-s [18].

2. The policy of mass privatization, provoked, in particular by accession to the WTO, International Monetary Fund and the World Bank. So, as per the WTO rules, public goods of member states (including spheres of education and healthcare) are services subject to privatization. IMF, the World Bank and WTO, making demands for privatization, put emphasis on the following: reduction or total abolition of state financing, cease of state adjustment of social goods price, encouragement of public sector privatization, admission of major US and European corporations to public services. The said measures are successful in the case of public goods sector competitiveness, its ability to stand competition with corporations of the developed countries, and in case when household income allows to purchase of paid services. The result of implementation of the said measures was human capital degradation in a number of underdeveloped countries that had joined the WTO and the World Bank. In the result of implementation of the World Bank requirements in Zimbabwe educational and healthcare spheres of that country, that used to be the best in Africa, had turned into degradating ones. The country faces lack of medical instruments and medicine, labour conditions and payment of health workers had deteriorated. The lack of finance for operational costs is compensated partially by imposition of charges for recording and treatment services. But in general, the majority of population, especially those living in rural locality, who are unable to pay different contributions, almost have no access to healthcare. Educational sector in Vietnam is facing the same problem, since higher learning fees became customary practice since the year 1990 [19].

3. Demographic deadlock is recorded presently in a number of countries with a considerably outworn human capital due to ageing of population. The high rate of persons who attained pension age, the baby-boom generation means the increased load on the sector of public goods and social guarantees. Demographic deadlock is characteristic for countries that have no economic means for pensioners social guarantees and settlement of population ageing problem. In the countries with developing economy, ageing in China is goes faster than in other countries. In 2050 people over 65 years will make one forth part of population, or 480 million. At the same time, with the ageing of population more and more resources will be allocated for elderly people keeping and healthcare [18].

Similar processes take place in Malaysia, according to data by Mafauzy M., where ratio of population over 60 years has also increased for all these years: from 5,2\% in 1970 and to 6,3\% in 2000. It is expected, that in 2020 this parameter will reach $9,8 \%$ of population[20].

Due to poor provision for old age in those countries, they become a burden on those states. The ageing population slows down economic development with growth of costs of old-age welfare. 
The more the state estranges itself from the sector of public goods, the more are the "market failures", and human capital would have to purchase paid public goods. That means that commercial projects will be supported to the disadvantage of social ones. The population would have to use extensively its human capital to enable purchase of public goods in the market.

Differentiation of society in terms of living standards and quality would gallop. Unavailability of public goods would result in deterioration of human capital quality and impoverishment of the country. Migrant runoff would increase, social instability would deepen.

The staged scheme of consolidation of traps of underproduction of public goods and social guarantees is shown in Figure 2.

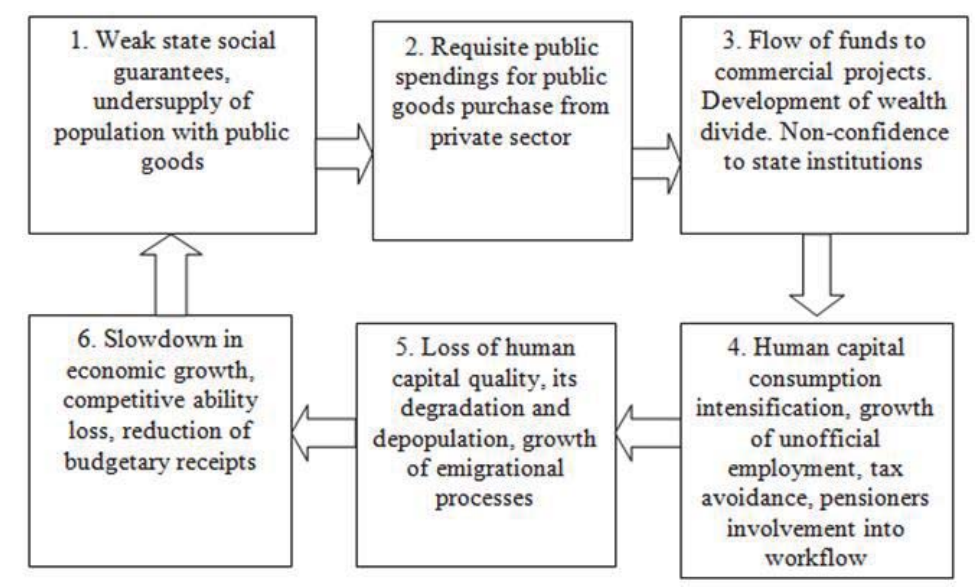

Fig. 2. Traps of underproduction of public goods and social guarantees.

As we may see from Figures 1 and 2, traps of public goods production are self-sustained and in default of state or public intervention may result in transformation of human capital into economic stagnation factor.

\section{Conclusion}

Represented materials give an opportunity to make conclusions on positive and negative effect of the scope and quality of public goods on the processes of human capital consumption. The matter is that the process of human capital consumption is the mechanism of correlation of demands and abilities. It is specific for human goods and social guarantees production that it effects both accumulation of human capital abilities, and lowers th need of its use, granting goods and services free of charge.

The unconsumed part of human capital may be concerned as a kind of deduction from the society wealth.

The traps of public goods production are characteristic both for developed and underdeveloped countries, and in all situations they are followed by strengthening public anger. Consolidation and rooting of institutional tramps of public goods production, that have been considered in this article, progresses in effect of several reasons at once, as it had happened in China and in some underdeveloped countries.

The issue of the ways of public goods and social guarantees effective system formation, maintaining a balance of human capital accumulation and consumption, is still the matter of contentious debates. It is well established that financial crisis had revealed the need of change of the budget course in implementation of public goods and social guarantees development programmes both in developed and underdeveloped countries, otherwise, the probability of dramatic budgetary situations is great.

\section{References}

Becker, G. (1964), 'Human capital', New York: Columbia University Press.

Schultz, T. (1960), "Capital Formation by Education," Journal of Political Economy, University of Chicago Press, vol. 68, pp. 571.

Mincer, J. (1958), 'Investment in human capital and personal income distribution', Journal of Political Economy, vol. 66, no. 4, pp. 281302. 
Expanding the Measure of Wealth / The World Bank Washington, Environment Department, 1997.

Source: Human Capital Index 2013. Scores are weighted by population; population data from United Nations Department of Economic and Social Affairs, World Population Prospects, rev. 2012.

Human Capital Index 2013 and the World Economic Forum's Global Competitiveness Index. Sept. 2013.

Abbas Q., (2000), The role of human capital in economic growth: a comparative study of Pakistan and India. Pakistan Development Review. Pakistan Institute of Development Economies, Islamabad, Pakistan. :39,2000,:p:457

Fuente de la A., Jimeno J. F. (2005), The Private and Fiscal returns to Schooling and the Effect of Public Policies on Private Incentives to Invest in Education: A General Framework and Same Results for the EU. CESifo Working Paper No. 1392, Category 4: Labour Markets, January.

Joshua C. (2006), Hall Positive Externalities and Government Involvement in Education // Journal of Private Enterprise. XXI, № 2

Lee J., Barro R.J, (2001), Schooling Quality in a Cross-Section of Countries, Economica, London School of Economics and Political Science, vol. 68(272), pp. 465-88, November.

Janet Currie, (2009), Healthy, Wealthy, and Wise: Socioeconomic Status, Poor Health in Childhood, and Human Capital Development, Journal of Economic Literature, American Economic Association, vol. 47(1), pp. 87-122, March.

Johnson R., Schoeni R. (2011), The Influence of Early-Life Events on Human Capital, Health Status, and Labor Market Outcomes Over the Life Course, The B.E. Journal of Economic Analysis \& Policy, De Gruyter, vol. 11(3), pp. 1-57, September.

Stiglitz J. Economics of the Public Sector, 3rd ed. - Norton, 2000

Robert J. Pauly, Jr., 2004. Islam in Europe: Integration or Marginalization Burlington, VT: Ashgate Publishing Company, p:57

Kukathas C. (1992), Theoretical Foundations of Multiculturalism Available at www.gmu.edu/departments/economics/pboettke/ workshop Ifall04/theoretical_foundations.pdf

OECD 2006, International Migration Outlook, data from Chart 1.2

WHO Department of Health Statistics and Informatics (May 15, 2013). "World Health Statistics 2013.

Banister J, Bloom DE, Rosenberg L. Population Aging and Economic Growth in China, Program on the Global Demography of Aging, Working Paper No. 53. Cambridge, MA: Harvard Center for Population and Development Studies, Harvard University; 2010. p:7.

Varghese N.V. (2007), GATS and higher education: the need for regulatory policies. International Institute for Educational Planning. http://unesdoc.unesco.org/images/0015/001506/150689e.pdf

Mafauzy M., (2000), The Problems and Challenges of the Aging Population of Malaysia. Malaysian Journal of Medical Sciences, 7 (1), pp. 1-3.

Maksutina E.V., Makarov A.N., Nazmeev E.F., Alpatova E.S. Assessment of economic efficiency of investments into the human capital in modern conditions. Life Science Journal 2014; 11 (6s): 376-379. 